\title{
CONTROL OF ARGENTINE STEM WEEVIL IN SEEDLING RYEGRASS
}

\section{T. E. T. TROUGHT}

Soil and Field Research Organisation, MAF, Lincoln

\section{Summary}

Trial data are presented which indicate that the seedlings of a range of grasses are susceptible to attack by adult Argentine stem weevil (Hyperodes bonariensis) and that the attack may result in the death of the seedlings. Protection against attack may be obtained by seed treatment with carbofuran or the drilling of carbofuran or phorate as granular formulations with the seed. Such protection with some varieties also reduces a later attack by weevil larvae and the combined effect of the protection is an increase in yield.

\section{INTRODUCTION}

Argentine stem wevil (Hyperodes bonariensis) is common in pastures throughout New Zealand. The importance of the weevil as a larval stem borer of graminaceous plants is well recognised. The adult, which feeds externally on the leaves, causes less serious damage to well established plants. The adult feeding on seedlings has, in the past, tended to be overlooked although, particularly under dry conditions, such an attack may kill a high proportion of the seedlings as they emerge.

This paper describes measures for protecting seedling grasses against adult attack and the benefit derived later from such protection.

\section{METHODS}

Field trials were carried out using a 10 coulter disc drill on land previously cultivated by the farmer. Granular insecticides, when applied, were mixed at appropriate rates with lime reverted superphosphate applied at the rate of $150 \mathrm{~kg} / \mathrm{ha}$ in the coulter with the seed which was sown at approximately $10 \mathrm{~kg} / \mathrm{ha}$. Sites were widely dispersed in Canterbury from the Lismore soils in the Ashburton county to the Templeton soils near Christchurch

Plots were $20 \times 3 \mathrm{~m}$ in a normal randomised block layout with 5 replicates except for the treatments in Table 6 which were sown by hand seeder as single row plots $10 \mathrm{~m}$ in length with 10 replicates.

Yields were assessed by cutting and weighing 5 random areas of $3.7 \mathrm{~m}^{2}$ per plot 4 months after sowing; seedling counts and tiller damage assessments were carried out approximately 3 and 8 weeks respectively after sowing.

Spray treatments (Table 2) were applied by knapsack sprayer soon after emergence.

Pot trials (Tables 1, 6 and 7) were carried out at a day temperature of $18^{\circ} \mathrm{C}$ and a night temperature of $13^{\circ} \mathrm{C}$ in the laboratory in $11.5 \mathrm{~cm}$ diameter pots artificially infested with weevil adults. In Table 1 clumps of approximately 5 seedlings of each species were presented, as choices, to 10 weevils caged before emergence of the seedlings : assessments were by eye score comparisons of the degrees of damage to the seedlings by adult feeding 3 days after all seedlings had emerged and, subsequently, 3 and 5 days later. 
Crop Pests

TABLE 1 : SUSCEPTIBILITY OF THE SEEDLINGS OF A NUMBER OF GRASS CULTIVARS AND SPECIES TO ADULT ARGENTINE STEM WEEVIL ATTACK IN POTS.

(Assessments by scoring 0 for no damage to 10 for very severe damage.)

\begin{tabular}{lc} 
Variety/species & $\begin{array}{c}\text { Scores for damage } \\
\text { (mean of } \\
\text { replicates) }\end{array}$ \\
\hline Ryegrass, 'Grasslands Paroa' (Lolium multiflorum) & $6.7 \mathrm{aA}$ \\
Ryegrass, 'Grasslands Ariki' N928 (L. hybrid) & $6.3 \mathrm{abA}$ \\
Ryegrass, 'Grasslands Ruanui' (L. perenne) & $5.3 \mathrm{abA}$ \\
Cocksfoot (Dactylis glomerata) & $5.3 \mathrm{abA}$ \\
Ryegrass, 'Grasslands Manawa' (L. hybrid) & $5.0 \mathrm{bA}$ \\
Timothy (Phleum pratense) & $3.0 \mathrm{cB}$ \\
Ryegrass, 'Grasslands Nui' (L. perenne) & $2.7 \mathrm{cBC}$ \\
Ryegrass, 'Grasslands Ariki' N889 & $0.8 \mathrm{dC}$ \\
CV \% & 32.0 \\
\hline
\end{tabular}

TABLE 2: THE EFFECTS OF VARIOUS CHEMICAL TREATMENTS ON SEEDLING ESTABLISHMENT OF SUMMER SOWN 'GRASSLANDS TAMA' RYEGRASS (L. multiflorum) (1973)

\begin{tabular}{|c|c|c|c|}
\hline \multirow[b]{2}{*}{ Treatments } & \multicolumn{3}{|c|}{ Mean number seedlings/m } \\
\hline & site 1 & site 2 & site 3 \\
\hline $\begin{array}{l}\text { phorate } G^{*} 2 \mathrm{~kg} / \mathrm{ha} \\
\text { carbofuran } \mathrm{G}^{*} 1 \mathrm{~kg} / \mathrm{ha} \\
\text { untreated } \\
\text { carbofuran } 10 \% \mathrm{CS} \dagger \\
\text { untreated CS } \dagger\end{array}$ & $\begin{aligned} 14.9 \mathrm{cB} \\
24.4 \mathrm{aA} \\
9.3 \mathrm{dC} \\
19.7 \mathrm{bAB} \\
8.9 \mathrm{dC}\end{aligned}$ & $\begin{array}{l}31.6 \mathrm{aA} \\
27.9 \mathrm{bB} \\
27.5 \mathrm{bB} \\
22.4 \mathrm{cC} \\
19.9 \mathrm{dD}\end{array}$ & $\begin{array}{r}15.9 \mathrm{aA} \\
10.4 \mathrm{bB} \\
6.4 \mathrm{cBC} \\
12.5 \mathrm{bAB} \\
3.9 \mathrm{cC} \\
\end{array}$ \\
\hline
\end{tabular}

$* \mathrm{G}=$ Granules

$\dagger \mathrm{CS}=$ Seed commercially coated with lime reverted superphosphate \pm $10 \% \mathrm{w} / \mathrm{w}$ carbofuran.

Note: It was difficult, with the machinery used, to adjust the seeding rate to the point where the output of untreated seed in treatments 1,2 and 3 could be guaranteed to be identical with that of coated seed in treatments 4 and 5 .

TABLE 3: EFFECTS OF VARIOUS TREATMENTS AT SOWING ON TILIER ATTACK BY ARGENTINE STEM WEEVIL LARVAE ON SPRING SOWN 'MANAWA' RYEGRASS (1972)

\begin{tabular}{|c|c|c|c|c|}
\hline \multirow[b]{2}{*}{ Treatments } & \multirow[b]{2}{*}{$k g / h a$} & \multicolumn{3}{|c|}{$\%$ tillers damaged } \\
\hline & & site 1 & site 2 & site 3 \\
\hline $\begin{array}{l}\text { carbofuran } 10 \% \text { seed treatment } \\
* \text { phorate } \\
* \text { disulfoton } \\
* \text { fensulfothion } \\
\dagger \text { chlorpyrifos } \\
\dagger \text { trichlorfon } \\
\dagger \text { omethoate } \\
\text { untreated }\end{array}$ & $\begin{array}{l}2 \\
1 \\
1 \\
2 \\
2 \\
2\end{array}$ & $\begin{array}{l}13.0 \mathrm{cC} \\
31.6 \mathrm{bB} \\
\overline{34} .6 \mathrm{~dB} \\
- \\
\overline{-}\end{array}$ & $\begin{array}{l}5.6 \mathrm{fE} \\
14.3 \mathrm{eD} \\
17.0 \mathrm{eD} \\
22.6 \mathrm{dC} \\
28.0 \mathrm{cB} \\
30.0 \mathrm{bcAB} \\
32.3 \mathrm{abAB} \\
33.5 \mathrm{abA}\end{array}$ & $\begin{array}{l}21.1 \mathrm{cB} \\
34.2 \mathrm{bA} \\
\overline{36.0} \mathrm{abA} \\
- \\
\overline{35} .3 \mathrm{abA} \\
39.9 \mathrm{aA}\end{array}$ \\
\hline
\end{tabular}

* Applied with seed at drilling.

$\dagger$ Applied at emergence of seedlings as spray. 


\section{RESULTS}

In $1975-76$ protected $(3 \% \mathrm{w} / \mathrm{w}$ carbofuran treated seed with $2 \mathrm{~kg} / \mathrm{ha}$ phorate sown with the sced) and unprotected seed of 'Tama' ryegrass were sown at 2 -week intervals from late October through to early February in replicated plots. There was no apparent loss of seedlings due to adult Argentine stem weevil attack at any time although there was ample evidence that they were feeding upon the seedlings. 1975-76 was a wet cool season compared with the trials in 1972-73 and it may be surmised that the weather and soil conditions markedly affect the degree to which seedlings suffer from adult attack.

\section{CONCLUSIONS}

A number of commonly grown grasses are susceptible to attack by adult Argentine stem weevils (Table 1). Such attack may, under the appropriate soil and weather conditions, result in the death of a high proportion of the seedlings. Protection against such attack may be afforded by a seed treatment with carbofuran or by the drilling of phorate or carbofuran as granules with the seed (Table 2 and 6). A moderate increase in the seed rate does not appear to be enough to raise the establishment of untreated seed to an acceptable level when under attack by adult weevils (Table 5).

Protection of seedlings of some varieties by insecticides also results in a reduced larval attack at a later stage (Tables 3 and 4) - this would seem to be due to the death of adults which have been in contact with or fed upon the insecticides used in the protection of the seed (Table 7). As a result both of the protection of the seedlings which gives a better stand of grass, and a reduction in the later larval attack, considerable yield increases can be obtained (Table 4).

\section{ACKNOWLEDGEMENTS}

Thanks are extended to the many farmers who permitted trials to be carried out on their land, to Mr A. L. Wood who assisted in the laying down and assessment of the trials and to Ms Joan Pearson who analysed the results.

TABLE 5: COMPARISON OF THE PROTECTION GIVEN TO EMERGING 'TAMA' RYEGRASS SEEDLINGS AGAINST ADULT ARGENTINE STEM WEEVILS BY TWO RATES OF SEED TREATMENT (AUTUMN 1973)

\begin{tabular}{llrrrr} 
& \multicolumn{5}{c}{ Mean number seedlings/m 4 weeks after sowing } \\
Treatments & Rate sown $:$ & $10 \mathrm{~kg} / \mathrm{ha}$ & $20 \mathrm{~kg} / \mathrm{ha}$ & $40 \mathrm{~kg} / \mathrm{ha}$ \\
\hline carbofuran 5\% & ST $^{*}$ & $15.5 \mathrm{~A}$ & $21.0 \mathrm{~A}$ & $36.5 \mathrm{~A}$ \\
carbofuran $10 \%$ & ST $^{*}$ & $13.5 \mathrm{~A}$ & $18.3 \mathrm{~A}$ & $33.5 \mathrm{~A}$ \\
untreated & $7.9 \mathrm{~B}$ & $10.5 \mathrm{~B}$ & $13.7 \mathrm{~B}$ \\
\hline
\end{tabular}

${ }^{*} \mathrm{ST}=$ Seed treatment using methyl cellulose sticker.

TABLE 6: EFFECT OF ARGENTINE STEM WEEVIL ON EMERGENCE AND SURVIVAL OF 'TAMA' SEEDLINGS IN POTS

(One adult caged per pot of 5 seed sown. Five replicates.)

\begin{tabular}{|c|c|c|c|}
\hline Treatment & & $\begin{array}{c}\text { Mean number } \\
4 \text { days after sowing }\end{array}$ & $\begin{array}{l}\text { live seedlings/pot } \\
8 \text { days after sowing }\end{array}$ \\
\hline $\begin{array}{l}\text { seed treated } 1 \% \mathrm{w} / \mathrm{w} \\
\text { seed treated } 3 \% \mathrm{w} / \mathrm{w} \\
\text { untreated }\end{array}$ & $\begin{array}{l}\text { carbofuran } \\
\text { carbofuran }\end{array}$ & $\begin{array}{l}4.4 \\
3.4 \\
0.4\end{array}$ & $\begin{array}{l}4.6 \\
4.4 \\
0\end{array}$ \\
\hline
\end{tabular}


Crop Pests

TABLE 7: SURVIVAL OF ADULT ARGENTINE STEM WEEVILS FEEDING ON 'MANAWA' SEEDLINGS FROM CORBOFURAN $(1.5 \% \mathrm{w} / \mathrm{w})$ TREATED SEED.

( 5 adults caged per pot of 5 seeds.)

\begin{tabular}{cc}
\hline Treatment & $\begin{array}{c}\text { Mean } \% \text { survival } \\
\text { (5 replicates) }\end{array}$ \\
\hline Seedlings from treated seed & $4 \%$ \\
Seedlings from untreated seed & $96 \%$ \\
\hline
\end{tabular}

Note : Seeds were covered to a depth of $2.5 \mathrm{~cm}$ by sterile soil and weevils survived on the soil surface until seedling emergence.

TABLE 4: EFFECTS OF VARIOUS TREATMENTS AT SOWING ON

TILLER ATTACK BY ARGENTINE STEM WEEVIL LARVAE ON

AUTUMN SOWN 'TAMA' RYEGRASS AND FIRST WINTER YIELD AUTUMN SOWN 'TAMA' RYEGRASS AND FIRST WINTER YIELD (1973)

\begin{tabular}{|c|c|c|c|c|c|c|}
\hline & \multicolumn{3}{|c|}{$\%$ Tillers damaged } & \multicolumn{3}{|c|}{ Yields kg DM/ha } \\
\hline $\begin{array}{l}\text { Treatment } \\
\text { phorate } G \quad 2 \mathrm{~kg} / \mathrm{ha} \\
\text { carbofuran } \mathrm{G} 1 \mathrm{~kg} / \mathrm{ha} \\
\text { untreated } \\
\text { carbofuran } 10 \% \quad \mathrm{CS}^{*} \\
\text { untreated CS* }\end{array}$ & $\begin{array}{l}\text { site } 1 \\
4.3 \mathrm{cC} \\
0.0 \mathrm{dD} \\
9.1 \mathrm{bB} \\
2.6 \mathrm{cdCD} \\
15.0 \mathrm{aA}\end{array}$ & $\begin{array}{l}\text { site } 2 \\
4.3 \mathrm{dDC} \\
8.4 \mathrm{cC} \\
42.8 \mathrm{aA} \\
1.4 \mathrm{dD} \\
36.6 \mathrm{bB}\end{array}$ & $\begin{array}{r}\text { site } 3 \\
2.9 \mathrm{cC} \\
2.3 \mathrm{cC} \\
22.4 \mathrm{bB} \\
0.6 \mathrm{cC} \\
26.4 \mathrm{aA}\end{array}$ & $\begin{array}{l}\text { site } 4 \\
21.1 \mathrm{cB} \\
28.0 \mathrm{cB} \\
48.0 \mathrm{aA} \\
10.5 \mathrm{dC} \\
38.8 \mathrm{bA}\end{array}$ & $\begin{array}{ll}\text { site } & 1 \\
747 & \mathrm{~A} \\
583 & \mathrm{~B} \\
200 & \mathrm{D} \\
437 & \mathrm{C} \\
180 & \mathrm{D}\end{array}$ & $\begin{array}{rl}\text { site } & 2 \\
2259 & \mathrm{~A} \\
2031 & \mathrm{AB} \\
646 & \mathrm{C} \\
1826 & \mathrm{~B} \\
337 & \mathrm{C}\end{array}$ \\
\hline
\end{tabular}

* See notes Table 2. 